\title{
Natural Gas and Efficient Technologies A Response to Global Warming
}

\author{
by \\ Meyer Steinberg \\ Brookhaven National Laboratory \\ Upton, New York 11973
}

\section{MASTER}

February 1998

Engineering Technology Division

Department of Advanced Technology, Brookhaven National Laboratory

Upton, New York 11973

Prepared for the U.S. Department of Energy

Washington, DC

Contract No. DE-AC02-98CH10886 
This report was prepared as an account of work sponsored by an agency of the United States Government. Neither the United States Government nor any agency thereof, nur any of their employees, or any of their contractors, subcontractors, or their employees, makes any warrantee, expressed or implied, or assumes any legal liabilities or responsibility for the accuracy, completeness, or usefulness of an information, apparatus, product, or process disclosed, or represents that its use would not infringe privately owned rights. Reference herein to any specific commercial product, process or service by trade name, trademark, manufacturer, or otherwise, does not necessarily constitute or imply its endorsement, recommendation, or favoring by the United States Government or any agency, contractor, or subcontractor thereof. The views and opinions of authors expressed herein do not necessarily state or reflect those of the United States Government or any agency contractor or subcontractor thereof. 


\title{
Natural Gas and Efficient Technologies A Response to Global Warming
}

\author{
by \\ Meyer Steinberg \\ Brookhaven National Laboratory \\ Upton, NY 11973 \\ February 1998
}

\begin{abstract}
:
It has become recognized by the international scientific community that global warming due to fossil fuel energy buildup of greenhouse $\mathrm{CO}_{2}$ in the atmosphere is a real environmental problem. Worldwide agreement has also been reached to reduce $\mathrm{CO}_{2}$ emissions. A leading approach to reducing $\mathrm{CO}_{2}$ emissions is to utilize hydrogen-rich fuels and improve the efficiency of conversion in the power generation, transportation and heating sectors of the economy. In this report, natural gas, having the highest hydrogen content of all the fossil fuels, can have an important impact in reducing $\mathrm{CO}_{2}$ emissions. This paper explores natural gas and improved conversion systems for supplying energy to all three sectors of the economy. The improved technologies include combined cycle for power generation, the Carnol system for methanol production for the transportation sector and fuel cells for both power generation and transportation use. The reduction in $\mathrm{CO}_{2}$ from current emissions range from 13\% when natural gas is substituted for gasoline in the transportation sector to $45 \%$ when substituting methanol produced by the Carnol systems (hydrogen from thermal decomposition of methane reacting with $\mathrm{CO}_{2}$ from coal-fired power plants) used in the transportation sector. $\mathrm{CO}_{2}$ reductions exceeding $60 \%$ can be achieved by using natural gas in combined cycle for power generation and Carnol methanol in the transportation sector and would, thus, stabilize $\mathrm{CO}_{2}$ concentration in the atmosphere predicted to avoid undue climate change effects. It is estimated that the total fossil fuel energy bill in the U.S. can be reduced by over $40 \%$ from the current fuel bill. This also allows a doubling in the unit cost for natural gas if the current energy bill is maintained. Estimates of the total net incremental replacement capital cost for completing the new improved equipment is not more than that which will have to be spent to replace the existing equipment conducting business as usual. The improved natural gas economy set forth here, resulting in stabilization of atmospheric $\mathrm{CO}_{2}$ is predicated on (1) availability of long term supply of natural gas, the potential of which resides in its economical extraction from abundant methane hydrates deposits; (2) development of an efficient Carnol process for methanol production based on thermal decomposition of methanal gas and (3) development of an efficient direct liquid methanol fuel cell for automotive use.
\end{abstract}




\title{
NATURAL GAS AND EFFICIENT TECHNOLOGIES A RESPONSE TO GLOBAL WARMING
}

\author{
Meyer Steinberg \\ Brookhaven National Laboratory \\ Upton, NY 11973 \\ February 1998
}

\section{INTRODUCTION}

Global Warming (others like to call it Global Climate Change) as a result of increasing greenhouse gas buildup in the earth's atmosphere, particularly $\mathrm{CO}_{2}$ gas from the combustion of fossil fuels (coal, oil and gas) has gained increasing attention of the nations of the world over the past decade. Numerous national and international conferences have been held on the subject, and a consensus among 2500 of the world's leading scientists has concluded that despite uncertainties, a discernable temperature effect can be attributed to man's emissions of $\mathrm{CO}_{2}$ introduced into the atmosphere because of the need of the world's population to generate energy through the combustion of fossil fuels. ${ }^{(1)}$ The general projections are that the $\mathrm{CO}_{2}$ emissions will double in the atmosphere within the next century (from the 1995 level of $350 \mathrm{ppm}$ to about $750 \mathrm{ppm}$ $\mathrm{CO}_{2}$ ) which could cause the earth's surface temperature to rise from $2.0^{\circ}$ to $4.5^{\circ} \mathrm{C}$. This would melt the antarctic polar icecap and increase the ocean level about an average of $50 \mathrm{~cm}(2 \mathrm{ft}$.) as well as cause other adverse environmental and health effects. The major $\mathrm{CO}_{2}$ emitters are the industrially developed countries including the United States, Russia, Japan and European countries. Of particular concern are the large developing countries which mainly include China and India since they rely mainly on fossil fuels (and particularly coal) to bring their standards of living up to the level of the developed countries. There is a natural tendency to resist any $\mathrm{CO}_{2}$ restrictions that the developed countries might be attempting to impose on the developing countries. The developed countries have their own internal problems of convincing their own industries to accept restrictions on their $\mathrm{CO}_{2}$ emissions because they see this as a negative effect on their economy. However, some leading industries are beginning to recognize the problem and that searching for technological responses to the challenge of mitigating the effect should be cautiously pursued. Adapting to the effect of global warming (i.e., move to higher ground) is recognized as an alternative response to mitigation, and should be considered in terms of economically assessing the alternatives.

A useful equation which sums up the major factors for quantitatively determining $\mathrm{CO}_{2}$ emissions from a given country is the modified Kaya Equation, modified by a removal term. ${ }^{(1)}$

$$
\text { Net } \mathrm{C} \text { emissions as } \mathrm{CO}_{2}=P \times \frac{G D P}{P} \times \frac{E}{G D P} \times \frac{C}{E}-S
$$

Net Carbon Emissions as $\mathrm{CO}_{2}=$ Population $(\mathrm{P})$ and per Capita Gross Domestic to the atmosphere Product

$$
\begin{gathered}
\left(\frac{G D P}{P}\right) \\
\left(\frac{E}{G D P}\right) \\
\left(\frac{C}{E}\right)
\end{gathered}
$$

$\mathbf{x}$ Energy generated per Gross Domestic Product

$\mathrm{x}$ Carbon Emission per unit energy generated

-- Natural and induced removal of $\mathrm{C}$ as $\mathrm{CO}_{2}$ from atmosphere 
The primary cause of greenhouse gas is the size of the population, $\mathrm{P}$, which demands and consumes the energy. The products (GDP) generated by the public, which reflects the standard of living, is next in importance. The third term is related to the efficiency or the amount of energy consumed to produce the products. The last term deals with the quality of the fuel in terms of amount of carbon as $\mathrm{CO}_{2}$ emitted per unit of energy derived from the fuel. When determining net $\mathrm{CO}_{2}$ emission, a removal or sink term, $\mathrm{S}$, must be subtracted from the emission equation which can be either natural removal (i.e., reabsorption in trees and plants) or technologically induced (i.e., $\mathrm{CO}_{2}$ removal technologies from fossil fuel power plant stacks).

In terms of the application of $\mathrm{CO}_{2}$ mitigation strategies, lower energy per unit of GDP and lower carbon emitted per unit of energy produced $(\mathrm{C} / \mathrm{E})$ are the more relevant factors, both of which opt for more efficient means of generating energy and producing goods.

This paper mainly addresses the E/GDP, C/E and S terms and attempts to quantify the effect of energy efficiency, fuel substitution as well as carbon removal and sequestration.

\section{$\mathrm{CO}_{2}$ Emissions from Various Energy Sources}

The combustion of coal produces the highest emission of $\mathrm{CO}_{2}$ per unit of energy released. Natural gas gives the least $\mathrm{CO}_{2}$ emission, and oil is about half way between coal and oil. Table 1 shows the average emissions rates for each of the major natural fossil fuel sources.

Table 1

$\mathrm{CO}_{2}$ Emissions from Combustion of Fossil Fuel ( $\mathrm{C} / \mathrm{E}$ term)

\begin{tabular}{|c|c|c|}
\hline Fossil Fuel & $\begin{array}{c}\mathrm{CO}_{2} \text { Emission } \\
\text { Lbs C0 } / \mathrm{MMBTU}\end{array}$ & $\mathrm{Kg} \mathrm{CO}_{2} / \mathrm{GJ}$ \\
\hline $\mathrm{Coal}^{\mathrm{a}}$ & 215 & 93 \\
\hline $\mathrm{Oil}^{\mathrm{b}}$ & 160 & 69 \\
\hline $\mathrm{Gas}^{\mathrm{c}}$ & 115 & 49 \\
\hline
\end{tabular}

a Coal assumes HHV of $11,000 \mathrm{BTU} / \mathrm{Lb}$ and a carbon content of $76 \%$ by weight.

b Oil assumes a composition of $\mathrm{CH}_{1.8}$ and $\mathrm{HHV}$ of $6 \mathrm{MMBTU} / \mathrm{bbl}$

c Gas assumes HHV of $1 \mathrm{MBTU} / \mathrm{cu} . \mathrm{ft}$.

$\mathrm{HHV}=$ higher heating value, $\mathrm{MMBTU}=10^{6} \mathrm{BTU}, \mathrm{MBTU}=10^{3} \mathrm{BTU}$

Converting Lbs $\mathrm{CO}_{2} / \mathrm{MMBTU}$ to $\mathrm{Kg} \mathrm{CO}_{2} / \mathrm{GJ}$, Multiply by 0.434

An assessment is made for various scenarios in substituting fuels and estimating the effect on $\mathrm{CO}_{2}$ emissions. It should be pointed out that by removing carbon either as $\mathrm{C}$ or as $\mathrm{CO}_{2}$ from fuels referred to as "decarbonization" either prior to or after combustion, the $\mathrm{C} / \mathrm{E}$ term becomes modified. The term "Sequestration" refers to the long term disposal and storage of $\mathrm{C}$ or $\mathrm{CO}_{2}$. 


\section{Current U.S. Energy Consumption and $\mathrm{CO}_{2}$ Emission}

The scenarios are applied to the recent energy consumption in the U.S. Table 2 shows fuel consumption, energy consumption by fuel and the $\mathrm{CO}_{2}$ emissions by fuel type for the year 1995. ${ }^{(1)}$ Table 2 also shows the world total. The U.S. consumes about $23 \%$ of the energy consumption in the world and generates and emits about $27 \%$ of the world's $\mathrm{CO}_{2}$ emissions.

Table 2

Total Fossil Fuel Energy Consumption and $\mathrm{CO}_{2}$ Emission for the U.S. in $1995^{(3)}$

\begin{tabular}{|c|c|c|c|c|c|}
\hline \multirow[t]{2}{*}{ Fuel Type } & \multirow[t]{2}{*}{ Quantity } & \multirow{2}{*}{$\begin{array}{c}\text { Energy } \\
\text { Consumption } \\
\text { Q BTU }\end{array}$} & \multirow{2}{*}{$\begin{array}{c}\text { Principal } \\
\text { Energy } \\
\text { Service }\end{array}$} & \multicolumn{2}{|c|}{$\mathrm{CO}_{2}$ Emission } \\
\hline & & & & $\mathrm{GT}\left(\mathrm{CO}_{2}\right)$ & $\%$ \\
\hline Coal & $0.9 \times 10^{9}$ tons & 20 & electricity & 2.15 & $35 \%$ \\
\hline Oil & $5.8 \times 10^{9} \mathrm{bbls}$ & 35 & $\begin{array}{c}\text { Auto } \\
\text { transport }\end{array}$ & 2.80 & $45 \%$ \\
\hline Gas & $21.0 \mathrm{TCF}$ & 21 & heating & 1.21 & $20 \%$ \\
\hline $\begin{array}{l}\text { U.S. Total } \\
\text { World Total }\end{array}$ & & $\begin{array}{c}76 \\
330\end{array}$ & & $\begin{array}{c}6.16(1.68 \mathrm{GT}(\mathrm{C})) \\
22.7(6.2 \mathrm{GT}(\mathrm{C}))\end{array}$ & \\
\hline
\end{tabular}

$\mathrm{TCF}=$ Trillion $\left(10^{12}\right)$ cubic feet

$\mathrm{GT}=\mathrm{Giga}\left(10^{9}\right)$ tons

$\mathrm{Q}=$ Quads $\left(10^{15}\right) \mathrm{BTU}$

In the U.S., most of the coal is used for generation of electrical power, in large central power stations. Oil is mainly used for production of transportation fuel (gasoline and diesel) with some limited electrical power production and gas is mainly used for industrial and domestic heating. However, there is also lately a growing consumption of natural gas for electrical power production.

\section{Substituting Natural Gas for Coal for Electrical Power Production}

If all the current electrical power production in the U.S. is generated by natural gas in a combined cycle power plant, two benefits of $\mathrm{CO}_{2}$ emission are achieved. First, the efficiency of electrical power production is increased from the current average coal-fired plant efficiency of $38 \%$ to $55 \%$ for a modern natural gas fired turbine combined cycle plant and secondly the $\mathrm{CO}_{2}$ emission per unit of energy is reduced by $47 \%$ compared to the coal-fired plant. Applying this to the U.S. consumption, Table 3 gives the $\mathrm{CO}_{2}$ emission for this scenario. 
Table 3

$\mathrm{CO}_{2}$ Emission When NG Substitutes For All Coal

In a Combined Cycle for Electrical Power Production

Current-coal-fired plant efficiency $38 \%$

NG combined cycle efficiency $55 \%$

\begin{tabular}{|c|c|c|c|c|}
\hline Fuel Type & $\begin{array}{c}\text { Natural Gas } \\
\text { Consumption } \\
\text { Quads }\end{array}$ & $\begin{array}{c}\text { Energy Consumed } \\
\text { Quads }\end{array}$ & Energy Service & $\begin{array}{c}\mathrm{CO}_{2} \text { Emission } \\
\mathrm{GT}\left(\mathrm{C}_{2}\right)\end{array}$ \\
\hline $\begin{array}{c}\text { Gas substituted for } \\
\text { coal }\end{array}$ & 14 & 14 & Electricity & 0.79 \\
\hline Oil & -- & 35 & Auto Transport & 2.80 \\
\hline Gas & 21 & 21 & Heating & 1.21 \\
\hline Total & 35 & 70 & & 4.80 \\
\hline & & Reduction from current $\mathrm{CO}_{2}$ emission & 1.36 \\
\hline
\end{tabular}

Thus, it is seen that there is a $22 \%$ reduction in overall $\mathrm{CO}_{2}$ emission in the U.S. when natural gas is substituted for coal in combined cycle plant for all electrical power production. This scenario also assumes that natural gas usage remains approximately the same for supplying heat to the industrial and domestic sectors.

\section{Substituting Natural Gas for Oil for Automotive Transportation}

If natural gas is substituted for oil in the transportation sector at the same efficiency, the reduced $\mathrm{CO}_{2}$ emission is calculated in Table 4.

Table 4

$\mathrm{CO}_{2}$ Emission When Natural Gas Is Substituted for Oil in the Transportation Sector

\begin{tabular}{|c|c|c|c|c|}
\hline Fuel Type & $\begin{array}{c}\text { Natural Gas } \\
\text { Consumed } \\
\text { Quads }\end{array}$ & $\begin{array}{c}\text { Energy Consumed } \\
\text { Quads }\end{array}$ & Energy Service & $\begin{array}{c}\mathrm{CO}_{2} \text { emission } \\
\mathrm{GT}\left(\mathrm{CO}_{2}\right)\end{array}$ \\
\hline Coal & - & 20 & Electricity & 2.15 \\
\hline $\begin{array}{l}\text { Gas substituted for } \\
\text { oil }\end{array}$ & 35 & 35 & Auto Transport & 2.01 \\
\hline Gas & 21 & 21 & Heating & 1.21 \\
\hline Total & 56 & 76 & & 5.37 \\
\hline \multicolumn{4}{|c|}{ Reduction from current $\mathrm{CO}_{2}$ emission } & 0.79 \\
\hline \multicolumn{4}{|c|}{$\% \mathrm{CO}_{2}$ reduction from 1995 level } & $12.8 \%$ \\
\hline
\end{tabular}


Thus, it is seen that there is only a $12.8 \%$ reduction in $\mathrm{CO}_{2}$ when natural gas is substituted for oil in the transportation sector at the same automotive efficiency. Natural gas heating remains the same for the industrial and domestic sectors.

\section{Substituting Natural Gas for Coal and Oil for Electrical Power and Transportation Service}

If natural gas is substituted for all the coal and oil consumption in the U.S., the sum of the emission reduction would be $34.9 \%$, adding the results of Tables 3 and 4 .

The Carnol System for Preserving the Coal Industry for Electrical Power Production and Reducing Oil Consumption by Methanol in the Transportation Sector

The Carnol System consists of generating hydrogen by the thermal decomposition of methane ${ }^{(1)}$ and reacting the hydrogen produced with $\mathrm{CO}_{2}$ recovered from coal-fired central power stations to produce methanol as a liquid transportation fuel. ${ }^{(2)}$ Figure 1 illustrates the Carnol System which has the following advantages:

1. The Carnol System preserves the coal industry for electrical power production.

2. The Carnol System produces a liquid fuel for the transportation sector which fits in well with the current liquid fuel infrastructure.

3. The Carnol System reduces consumption of the dwindling domestic supplies of fuel oil in the U.S.

In the Carnol System, the carbon from the coal is used twice, once for production of electricity and a second time for production of liquid fuel for fueling the transportation sector, in automobile vehicles. The reduction in $\mathrm{CO}_{2}$ emissions results from two aspects. The elemental carbon produced from the thermal decomposition of the methane is not used as fuel. It is either sequestered or sold as a materials commodity. In this respect, thermal decomposition of methane (TDM) has an advantage over the conventional steam reforming of methane (SRM) for hydrogen production because in SRM the efficiency of hydrogen production includes the inefficiency separation and sequestering of the $\mathrm{CO}_{2}$ produced. In the $\mathrm{SRM}$ process, $\mathrm{CO}_{2}$ is produced, which must be sequestered either in underground aquifers or in the ocean and thus the efficiency of hydrogen production is reduced. ${ }^{(7)}$ In the TDM process only, carbon is produced as a solid which is much easier to sequester than $\mathrm{CO}_{2}$ as a gas. Furthermore, the energy in the carbon sequestered is still available for possible future retrieval and use. The carbon can also be used as a materials commodity, for example, as a soil conditioner.

Table 5 gives the estimate of the $\mathrm{CO}_{2}$ emission using the Carnol System based on the 1995 consumption of oil, gas and coal for energy generation in the various sectors. 
Fra. 1

\section{INTEGRATED SYSTEM FOR $\mathrm{CO}_{2}$ EMISSION REDUCTION}

CARNOL PROCESS

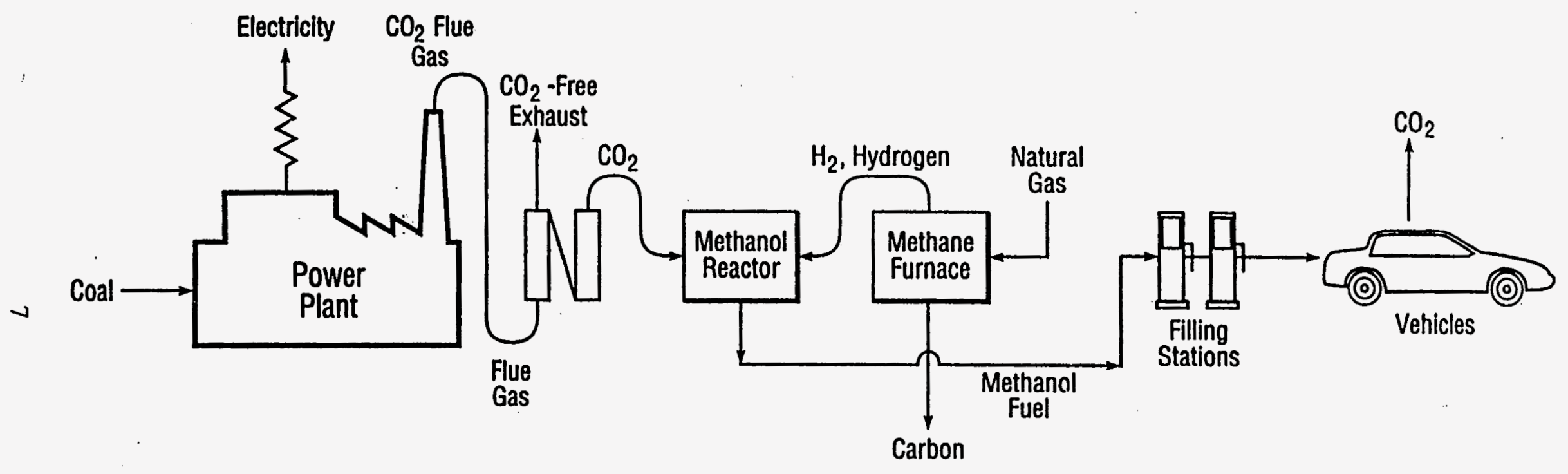

COALFIRED POWER PLANT

ELECTRICITY $\mathrm{CO}_{2}$-FREE EMISSION
CARNOL CHEMICAL PLANT

METHANOL PLANT $\mathrm{CO}_{2}$-FREE
AUTOMOTIVE FUEL USE REDUCED $\mathrm{CO}_{2}$ EMISSIOH 
Table 5

Carnol Methanol Substitution for Oil in the Conventional Auto Transportation Sector Produced from Natural Gas and $\mathrm{CO}_{2}$ from Coal-fired Power Plants

\begin{tabular}{|c|c|c|c|c|}
\hline Fuel Type & $\begin{array}{c}\text { Natural Gas } \\
\text { Consumed } \\
\text { Quads }\end{array}$ & $\begin{array}{c}\text { Energy Consumed } \\
\text { Quads }\end{array}$ & Energy Service & $\begin{array}{c}\mathrm{CO}_{2} \text { Emissions } \\
\text { GT }\left(\mathrm{CO}_{2}\right)\end{array}$ \\
\hline Coal $^{\mathrm{a}}$ & -- & 20 & Electricity & 0.22 \\
\hline $\begin{array}{c}\text { Methanol } \\
\text { substitutes for } \\
\text { gasoline }\end{array}$ & 41 & 24 & Auto Transport & 1.96 \\
\hline Gas & 21 & 21 & Heating & 1.21 \\
\hline Total & 62 & 65 & & 3.39 \\
\hline & \multicolumn{3}{|c|}{ Reduction from current $\mathrm{CO}_{2}$ emission } & 2.77 \\
\hline & $\% \mathrm{CO}_{2}$ Emission Reduction from 1995 level & $45.0 \%$ \\
\hline \multicolumn{4}{r|}{ Elemental carbon sequestered } & $0.58 \mathrm{GT}(\mathrm{C})$ \\
\hline
\end{tabular}

The following are explanatory notes for Table 5:

a. The coal consumption remains at $0.9 \mathrm{GT}$ which generates 20 quads of electricity and produces 2.15 GT of $\mathrm{CO}_{2} .90 \%$ of which is recovered by absorption-stripping with an MEA solvent. The power

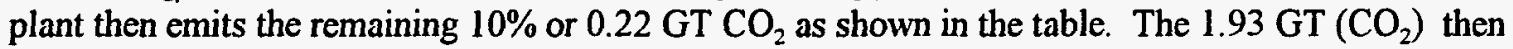
becomes available to the Carnol plant for producing methanol.

b. The $\mathrm{CO}_{2}$ from the power plant reacts with hydrogen from a methane decomposition reactor (MDR) which operates at $80 \%$ efficiency emitting $0.25 \mathrm{GT}\left(\mathrm{CO}_{2}\right)$ and producing 35 quads of methanol liquid fuel for automotive vehicles equivalent to that of oil consumption. The methanol combusted in the automotive vehicles emits $1.71 \mathrm{GT} \mathrm{CO}_{2}$ making up the $1.96 \mathrm{GT} \mathrm{CO}_{2}$ shown in the table for methanol $\mathrm{CO}_{2}$ emission. It should be noted that methanol is $30 \%$ more efficient than gasoline in IC internal combustion (IC) engines so that the $\mathrm{CO}_{2}$ emission is reduced accordingly ${ }^{(2)}$ and only $70 \%$ of the 35 quad or 24 quad is needed in the transportation sector. The $\mathrm{CO}_{2}$ recovered from the coal burning power plants matches the methanol production requirement at 24 quad. The natural gas requirement to produce 24 quad of methanol by the Carnol Process amounts to 41 Quad, which is about twice the current consumption of natural gas consumed for heating purposes. The sequestration of $0.58 \mathrm{GT}$ (C) is half the tonnage of coal mined in the U.S.

Table 5 indicates that the Carnol System can reduce the $\mathrm{CO}_{2}$ emission by $45 \%$ compared to current energy consumption and $\mathrm{CO}_{2}$ emission. The natural gas requirement would have to increase to 62 quad which is 3 times the current consumption of natural gas for heating purposes. The reason the requirement for natural gas increases so rapidly is because in the Carnol methanol plant, only about $58 \%$ of the natural gas energy is utilized for producing hydrogen for methanol, the remainder of the energy is sequestered as unburned carbon. Table 5 shows that $0.58 \mathrm{GT}$ is sequestered as elemental carbon. This can be considerably reduced by going to fuel cell vehicles as shown in the next scenario. 
Carnol System with Methanol Fuel Cells for the Transportation Sector and Substituting Natural Gas with Combined Cycle Power for Coal Fired Central Station Power

In the not too distant future, fuel cells will be developed for automotive vehicles. This will improve the efficiency of automotive engines by at least 2.5 times compared to current gasoline driven internal combustion engines. ${ }^{(8)}$ Direct liquid methanol fuel cells are under development. ${ }^{(11)}$ If we use coal or oil for central power stations, there will be too much $\mathrm{CO}_{2}$ generated for liquid fuel methanol by the Carnol Process for the transportation sector using fuel cells. Therefore, it is much more energy balanced if we use natural gas for power because it generates the least amount of $\mathrm{CO}_{2}$ per unit of energy. In this scenario, the natural gas in a combined cycle plant displaces coal for power production and displaces oil for methanol by the Carnol Process for transportation. The results are shown in Table 6.

Table 6

Natural Gas substituted for Coal Fired Power Production, Carnol Process for Methanol Production, Substituting for Oil in Fuel Cell Vehicles for the Transportation Sector

\begin{tabular}{|c|c|c|c|c|}
\hline Fuel Type & $\begin{array}{c}\text { Natural Gas } \\
\text { Consumption } \\
\text { Quads }\end{array}$ & $\begin{array}{c}\text { Energy } \\
\text { Consumption } \\
\text { Quads }\end{array}$ & Energy Service & $\begin{array}{c}\mathrm{CO}_{2} \text { Emission } \\
\mathrm{GT}\left(\mathrm{CO}_{2}\right)\end{array}$ \\
\hline $\begin{array}{l}\text { Natural gas for } \\
\text { coal }^{\mathbf{a}}\end{array}$ & 14 & 14 & Electricity & 0.08 \\
\hline Methanol for oil & 24 & 14 & $\begin{array}{l}\text { Auto Transport } \\
\text { Fuel Cells }\end{array}$ & 1.12 \\
\hline Gas & 21 & 21 & Heating & 1.21 \\
\hline Total & 59 & 49 & & 2.41 \\
\hline \multicolumn{4}{|c|}{ Reduction from Current $\mathrm{CO}_{2}$ Emissions } & 3.75 \\
\hline \multicolumn{4}{|c|}{$\% \mathrm{CO}_{2}$ Emission Reduction from 1995 level } & $61 \%$ \\
\hline \multicolumn{4}{|c|}{ Elemental carbon sequestered } & $0.34 \mathrm{GT}(\mathrm{C})$ \\
\hline
\end{tabular}

a) Natural gas for combined cycle power plant is $55 \%$ efficient and $90 \%$ of $\mathrm{CO}_{2}$ emissions is recovered for Carnol plant.

There is a small deficiency $(0.32 \mathrm{GT}) \mathrm{CO}_{2}$ in the availability of $\mathrm{CO}_{2}$ from the very efficient natural gas combined cycle plants to supply the Carnol methanol plant. This can be made up by allowing some (about $15 \%$ ) of the natural gas plants to operate in a standard plant at $38 \%$ efficiency to generate the additional $\mathrm{CO}_{2}$ to supply the Carnol plant for producing automotive methanol. It is also possible to utilize the $\mathrm{CO}_{2}$ that may be associated with the natural gas from the wells to make up for the deficiency of $\mathrm{CO}_{2}$ from the combined cycle natural gas fired power plants to supply the automotive Carnol methanol plant. Thus, by applying the all natural gas system for electrical power production, liquid fuels production for fuel cell driven automotive engines and for heating purposes in the industrial and domestic sectors, the overall $\mathrm{CO}_{2}$ emissions reductions of over $60 \%$ can be achieved. This degree of $\mathrm{CO}_{2}$ emission reduction could stabilize the $\mathrm{CO}_{2}$ concentration in the atmosphere and prevent the doubling of the $\mathrm{CO}_{2}$ in the atmosphere expected by the middle of the next century if business is conducted as usual. The $0.32 \mathrm{GT}$ of carbon sequestered is about 3 times less than the 
amount of coal mined in the U.S. currently. If a market can be found for this elemental carbon, such as a soil conditioner, the cost of methanol production can be significantly decreased.

The ultimate is to go to an all hydrogen economy producing hydrogen by thermal decomposition of methane for use in fuel cells for electrical power production, for transportation and for heating purposes. The $\mathrm{CO}_{2}$ would be essentially reduced by $100 \%$. Because of the higher efficiency the quantity of carbon for sequestration may be less then shown in Table 6. However, the production and handling of massive amounts of hydrogen probably will be a long time in coming, if ever.

\section{Natural Gas Supply and Utilization}

The all natural gas energy system of Table 6 requires a three-fold annual consumption in natural gas. Recent reports indicate that the current estimated reserve of conventional natural gas is of the same order of magnitude as the current estimated oil reserves which might last only another 80 years or so. However, unconventional resources, especially methane hydrates ${ }^{(9)}$ and coal bedded methane indicate an enormous resource which is estimated to be more than twice as large as all the fossil fuel resources currently estimated in the earth. If this is so, then we can begin to think of utilizing natural gas for reducing $\mathrm{CO}_{2}$ emissions in all sectors of the economy. It appears that even today that deep mined coal in several parts of the world, especially in England, Germany, and the U.S., has become too expensive; and, as a result, many of these mines have been closed. Most economical coal used now comes from surface mined coal. Furthermore, the contaminants in coal sulfur, nitrogen and ash in addition to the high $\mathrm{CO}_{2}$ emission mitigate against its use. Rail transportation of coal also becomes a problem compared to pipeline delivery of natural gas. When natural gas becomes available, even at a somewhat higher cost, it can displace coal and even oil for power production and transportation. Long term supply of economical natural gas is the main concern for utilization of natural gas.

\section{Economics of Natural gas Displacing Coal and Oil}

A cursory estimate of the economics of natural gas displacement in the U.S. can be obtained as follows: Table 7 indicates the unit price for each of the fossil fuels and the total energy bill for the U.S. over the last several decades.

Table 7

Unit Fossil Fuel Energy Cost and Total Fuel Cost for the U.S. - 1995 Basis

\begin{tabular}{|c|c|c|c|c|}
\hline Fuel Type & $\begin{array}{c}\text { Unit Energy Cost } \\
\text { \$/MMBTU }\end{array}$ & $\begin{array}{c}\text { Consumption } \\
\text { Quads }\end{array}$ & Energy Service & $\begin{array}{c}\text { Total Fuel Cost } \\
\$ 10^{9} \text { (\$ Billion) }\end{array}$ \\
\hline Coal & 1.00 & 20 & Electricity & 20 \\
\hline Oil & 3.00 & 35 & Auto Transport & 105 \\
\hline Gas & 2.00 & 21 & Heating & 42 \\
\hline Total & & 76 & & 167 \\
\hline
\end{tabular}

If we now supply these same unit costs to the all natural gas scenario presented in Table 6 above, we can draw up Table 8. 
Table 8

Fuel Cost for All Natural Gas Scenario

Combined Cycle Power and Fuel Cell Automotive Power

Based on natural gas Cost $=\$ \mathbf{2 . 0 0} / \mathrm{MMBTU}$

\begin{tabular}{|c|c|c|}
\hline Energy Demand Sector & $\begin{array}{c}\text { Consumption } \\
\text { Quads }^{\mathrm{a}}\end{array}$ & $\begin{array}{c}\text { Natural Gas Fuel Cost } \\
\text { \$10 (\$Billion) }\end{array}$ \\
\hline Electrical Power & 14 & 28 \\
\hline Automotive Power & 14 & 28 \\
\hline Industrial and Domestic Heating & 21 & 42 \\
\hline Total & 49 & 98 \\
\hline
\end{tabular}

a) from Table 6

Table 8 indicates that there is a $\$ 69$ Billion dollar decrease in the fossil fuel bill per year which is $41.3 \%$ lower than the current bill shown in Table 7 obtained by substituting an all natural gas economy for the current conventional coal and oil energy economy. It could also be pointed out that the cost of natural gas could go up to as high as $\$ 3.50 / \mathrm{MMBTU}$ to break even with today's fossil fuel energy bill. This cost is almost double the current natural gas cost and would allow for increased production cost of natural gas from unconventional sources. A carbon tax would make the incentive to go to natural gas that much greater.

We can now attempt to estimate the incremental capital investment for replacement of the present power production structure with the new more efficient technology. Table 9 indicates this incremental capitalization. The concept is that the current capital investment will be replaced under current business as usual conditions. Therefore, what we are concerned with is what additional capital cost will have to be incurred because of the replacement with new technology equipment.

Table 9

Capital Investment Required to Replace Present Power Structure

\begin{tabular}{|c|c|c|c|}
\hline $\begin{array}{l}\text { Present Power Structure } \\
\text { (and capacity) }\end{array}$ & $\begin{array}{l}\text { Replacement Structure } \\
\text { (and capacity) }\end{array}$ & $\begin{array}{l}\text { Incremental Unit } \\
\text { Capital Cost }\end{array}$ & $\begin{array}{c}\text { Incremental Replacement } \\
\text { Capital Cost } \\
\$ 10^{9}(\$ \text { Billions })\end{array}$ \\
\hline $\begin{array}{c}\text { Coal fired electrical a) } \\
\text { power } \\
400,000 \mathrm{MWe}\end{array}$ & $\begin{array}{l}\text { Natural gas fired } \\
\text { combined cycle } \\
\text { electrical power }\end{array}$ & $-\$ 1000 /$ kw (savings) $)^{\mathrm{a})}$ & $-\$ 400$ \\
\hline $\begin{array}{l}\text { Oil refineries }^{\text {b) }} \\
35 \text { Quads }\end{array}$ & $\begin{array}{c}\text { Carnol methanol plants } \\
14 \text { Quads }\end{array}$ & $\$ 10^{5} / \mathrm{T} / \mathrm{D}$ Methanol ${ }^{\mathrm{b})}$ & $+\$ 200$ \\
\hline Wells and pipelines ${ }^{c)}$ & $\begin{array}{c}\text { additional pipeline and } \\
\text { new methane hydrate } \\
\text { wells }\end{array}$ & $\begin{array}{c}\$ 10^{6} / \mathrm{mile}^{\mathrm{c})} \\
200,000 \text { miles of } \\
\text { gas lines }\end{array}$ & $+\$ 200$ \\
\hline $\begin{array}{l}\text { Automotive IC vehicles } \\
100 \times 10^{6}\end{array}$ & Fuel cell vehicles & $0^{d)}$ & $\sim 0$ \\
\hline \multicolumn{3}{|c|}{ Net total incremental replacement cost } & $\sim 0$ \\
\hline
\end{tabular}


The following are explanatory notes for Table 9:

a) For replacement of coal fired plants including scrubbers, etc., runs about $\$ 2000 / \mathrm{kw}(\epsilon)$, with the more efficient natural gas combined cycle plants runs about $\$ 1000 / \mathrm{KW}(\epsilon)$; thus, there is a $\$ 1000 / \mathrm{KW}(\epsilon)$ capital cost savings and when applied to an installed capacity of $400,000 \mathrm{MW}(\epsilon)$, the savings amounts to $\$ 400$ billion.

b) For replacing oil refineries with $\mathrm{Carnol}$ Methanol plants which require removal and recovery of $\mathrm{CO}_{2}$ from the natural gas plants, it is estimated that the current unit cost is $\$ 100,000$ per daily ton of methanol ${ }^{(10)}$ and the total incremental cost to supply 14 quads of methanol for fuel cell vehicles is $\$ 220$ Billion. Since no credit was taken for the replacement of oil refineries, over time, this incremental capital cost is probably high.

c) New pipelines will have to be built to transport the natural gas and new methods of extracting natural gas eventually from deep sea wells containing methanol hydrates. Assuming $\$ 1$ million per mile for these new gas supply facilities and a rough estimate of 200,000 miles needed gives a capital cost of roughly $\$ 200$ billion. It is also assumed that the liquid methanol pipeline and tanker distribution will be about equal to the current liquid gasoline distribution for the transportation sector.

d) In terms of replacing the current existing more than 100 million gasoline driven IC engine vehicles with fuel cell vehicles, it eventually should not cost much more than the present average cost of $\$ 15,000$ to $\$ 20,000$ per vehicle. And, so the incremental cost should be negligible and may even show a savings because of the more efficient fuel cell vehicle than the IC engine vehicle.

Thus, balancing the four power structures shown in Table 9, the incremental savings in the new technologies of the one electrical power sector just about balances the incremental cost in the other three sectors. Thus, the new total incremental capital replacement cost is a wash compared to the increasing capital cost requirement for continuing with the business as usual current power technology structures.

\section{Summary and Conclusions}

Table 10 summarizes the findings in this paper concerning natural gas fuel substitution and applying new efficient technologies. Natural gas substitution for oil in the transportation sector and coal in the power generation sector yields a $13 \%$ and $22 \%$ reduction in $\mathrm{CO}_{2}$ respectively compared to current $\mathrm{CO}_{2}$ emissions. Combining natural gas substitution in both sectors reduces $\mathrm{CO}_{2}$ by $35 \%$. Applying the new Carnol System producing methanol for conventional vehicles and obtaining the $\mathrm{CO}_{2}$ from coal fired power plant stacks reduces the $\mathrm{CO}_{2}$ emissions by $45 \%$. By going to an all natural gas energy economy with combined cycle power generation and using the $\mathrm{CO}_{2}$ from the natural gas power plant for producing methanol by the Carnol process and the methanol in efficient fuel cell automotive vehicles, can result in a $61 \%$ reduction $\mathrm{CO}_{2}$. The latter result should stabilize the $\mathrm{CO}_{2}$ emissions in the U.S. to well below the 1990 level. The all natural gas economy would require a three-fold increase in natural gas consumption compared to current consumption. For this all natural gas economy, the savings in the fuel bill for the U.S. can be as much as $\$ 69$ billion per year and the incremental capital investment required to replace the current technology with the new and improved efficiency technology would be negligible so that the cost of natural gas could almost double without adding to the burden of the current fuel economy. However, the all natural gas economy is predicated on the following assumptions and developments: 
Table 10

\section{Summary of the Effect of Natural Gas Substitutions and Efficient Technologies on $\mathrm{CO}_{2}$ Emission Reduction in the U.S.}

\begin{tabular}{|l|c|}
\hline \multicolumn{1}{|c|}{ Scenario } & $\begin{array}{c}\% \mathrm{CO}_{2} \text { Emissions Reduction } \\
\text { from 1995 level }\end{array}$ \\
\hline $\begin{array}{l}\text { Natural gas substitutes for oil in the conventional } \\
\text { transportation sector }\end{array}$ & $13 \%$ \\
\hline $\begin{array}{l}\text { Natural gas (combined cycle) substitutes for coal in } \\
\text { power generation }\end{array}$ & $22 \%$ \\
\hline $\begin{array}{l}\text { Natural gas substitutes for oil and coal in the above } \\
\text { transportation and coal power sectors }\end{array}$ & $35 \%$ \\
\hline $\begin{array}{l}\text { Carnol System with coal power plants supplying } \\
\text { CO }{ }_{2} \text { for methanol replacing oil in IC motor vehicles }\end{array}$ & $45 \%$ \\
\hline $\begin{array}{l}\text { Combined cycle natural gas substituting for coal in } \\
\text { power generation and Carnol for Methanol } \\
\text { production for fuel cell vehicles - all natural gas } \\
\text { economy }\end{array}$ & $61 \%$ \\
\hline
\end{tabular}

1. that there are vast reserves of natural gas that can be recovered from both conventional and nonconventional natural gas resources especially from methane hydrates and coal bedded methane at costs which are not more than about double current gas productions cost.

2. that an efficient Carnol process for methanol production based on thermal decomposition of methane can be achieved.

3. that an efficient direct methanol fuel cell vehicle can be developed.

The benefits in terms of mitigating global warming provides a strong incentive for working on and achieving the required development goals. The all natural gas economy with efficient technologies for $\mathrm{CO}_{2}$ global warming mitigation avoids alternatives of (1) sequestering $\mathrm{CO}_{2}$ in the ocean or underground, (2) switching to nuclear power, and (3) relying solely on solar and biomass energy. 


\section{$\underline{\text { References }}$}

1. Climate Change 1995, IPCC Report 1995, Working Group II in the Intergovernmental Panel on Climate Change, et al., Watson, R.T. et al (Eds.) Cambridge University Press, U.K., (1996).

2. Kaya, Y. et al., "A Grand Strategy for Global Warming," paper presented at Tokyo Conference on Global Environment (September 1989).

3. Carson, M.C., "Natural Gas Central to World's Future Energy Mix," Oil and Gas Journal, pp. 34-37 (August 11, 1997).

4. Steinberg, M., "Production of Hydrogen and Methanol from Natural Gas with Reduced $\mathrm{CO}_{2}$ Emission," Proceedings of the 11th World Hydrogen Energy Conference (WHEC), Vol. 1, pp. 499-510, Stuttgart, Germany, (June 23-28, 1996).

5. Steinberg, M., "Methanol as an Agent for $\mathrm{CO}_{2}$ mitigation," Energy Conversion $\underline{38}$ Supplement, pp. S423-S430 (1997).

6. U.S. Environmental Protection Agency, "Analyses of the Economic and Environmental Effects of Methanol as an Automotive Fuel," Research Report 0.730 (NTIS PB90-225806), Office of Mobile Sources, Ann Arbor, MI (1989).

7. Steinberg, M., "Natural Gas Decarbonization Technology for Mitigating Global Warming," BNL Report (in press) Brookhaven National Laboratory, Upton, NY (January 1998).

8. World Car Conference 1996, Bourns College of Engineering Center for Environmental Research and Technology, University of California, Riverside, CA (January 21-24, 1996).

9. Paul C., "Atlantic Gas Hydrates Target of Ocean Drilling Program, Target of Ocean Drilling Program Leg," Oil and Gas Journal, pp. 116-118 (October 16, 1995).

10. Steinberg, M., "CO 2 Mitigation and Fuel Production," BNL Report (in press), Brookhaven National Laboratory, Upton, NY (October 1997).

11. Halput, G., et al., "Direct Methanol Liquid-Field Fuel Cell," JPL Report, Jet Propulsion Laboratory, Pasadena, CA (May 1997). 


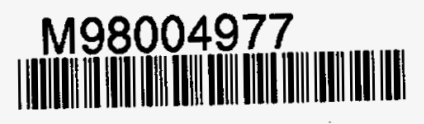

Report Number (14) BNL -65451

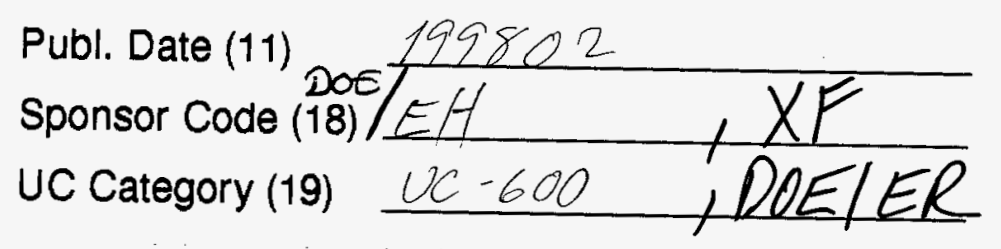

